\title{
Knowledge of leadership and management: pilot study of students perceptions of a dentistry course at a university in Brazil
}

\author{
Fábio Luiz Cunha D'Assunção*, Andressa Cartaxo de Almeida**, Elsbeth Kalenderian***
}

* Assistant Professor of Endodontics, Department of Restorative Dentistry, Federal University of Paraíba (UFPB)

** Dentist, trained by UFPB

*** Assistant Dean for Clinical Affairs and Interim Chair, Department of Oral Health Policy and Epidemiology, Harvard School of Dental Medicine - HSDM

\begin{abstract}
The Dentistry Course at UFPB was created in 1955. Although the course is recognized for its high-quality technical education in dentistry, through 2014, it has had no leadership and management subject, even though it is known that these skills are critical to the dentist. The aim of this research was therefore to evaluate the perceptions of knowledge about leadership and management of students in the fifth year of the UFPB dentistry course. Students answered a questionnaire and evaluated their current leadership skills on a scale from one (very poor) to five (excellent). On average, they rated themselves best on "Integrity" (4.42 points) and worst on "Advocacy skills" (2.38 points). The "ability to build others' trust" was the aspect considered most beneficial for an oral surgeon, representing $23.08 \%$ of responses, while "compassion" was the ability deemed least beneficial, with $34.62 \%$ of the responses. All students questioned agreed that it is important to
\end{abstract}

create leadership and management subject in the UFPB dentistry course. Little knowledge of leadership and management has been demonstrated, as well as a great need for creating a leadership course at UFPB.

Descriptors: Leadership. Dental Education. Dental Students. Practice Management.

\section{INTRODUTION}

The Dentistry course at UFPB, Brazil, was created in 1951, but it was not recognized until October $25^{\text {th }} 1955^{1}$. Thirty to forty students are enrolled biannually. Although it is a course recognized for its high-quality technical education in dentistry, it has no component relating to leadership and management activities ${ }^{2}$.

The Harvard School of Dental Medicine (HSDM) was founded in 1867 and was one of the first dental colleges in the United States. However, until 2009, there was no leadership skills course in the 
undergraduate curriculum.

In this context, Kalenderian et al. ${ }^{3}$ created a leadership course at HSDM. They saw this course as an opportunity to introduce these concepts and define their importance in dentistry. There was an understanding that these skills must be nurtured and developed throughout life. The authors found more than only immediate interest expressed by students, given the challenges that dentists face as professionals, community leaders, and dental educators.

Leadership in a clinical or research environment should include not only theoretical and conceptual classes but also practice in applying a broad set of skills, which include building rapport, compassion, facilitation, negotiation, communication, and development of emotional intelligence: skills that currently are not considered part of the curriculum ${ }^{3}$.

While there is an increasing demand for more humane medical practice that leaves patients and professionals more satisfied, such a practice is in danger of dying out. Of course, there are still dedicated health professionals who dispense caring and sensitive attention to the patient. However, while such care is considered an exception today, it could and should be the general trend, such that everyone can expect respectful treatment ${ }^{4}$.

The teaching of dentistry in UFPB, Brazil, must train professionals based on the principles of universality, comprehensiveness, equity, decentrallization and social participation. However, challenges remain in reducing socioeconomic disparities and developing public health measures for the most vulnerable groups ${ }^{5,6}$.
There is no citation in Political Pedagogical Projects of dentistry courses in Brazil (Projetos Políticos Pedagógicos PPPCOs) regarding the inclusion of specific leadership and management topics, whether in public or private service. ${ }^{7}$ Furthermore, there are no articles in the literature on the knowledge, perceptions and aspirations of dental students in the state of Paraíba, Brazil, regarding leadership. This study therefore aimed to evaluate UFPB dental students' perceptions regarding leadership and management and the need to instruct students on the subject.

\section{MATERIALS AND METHODS}

This research was a pilot study, a quantitative and transversal character, which applied questionnaires to achieve the desired objectives.

Students signed a consent form and were evaluated using a questionnaire similar to the one developed by Kalenderian et al. ${ }^{3}$ All students in the first semester of the fifth year of the UFPB undergraduate dental course were invited to answer the standard questionnaire on the Virtual UFPB/Moodle platform. They had a week to access the platform and answer the online questionnaire, individually, voluntarily, and in their own time. This standard questionnaire consisted of questions aimed at evaluating the leadership skills the students themselves possessed. In the first question, they scored their skills on a five-point scale ranging from very poor (one) to excellent (five). In the second question, they selected which of those aspects they found most and least beneficial to the dental profession, the probability of their developing these 
activities in clinical practice, what they would like to learn in a Leadership and Management course, and what new perceptions they think they would develop in a course similar to the HSDM course.
Figure 1 shows the personalized questionnaire used in the survey. All questions were considered, and comments were evaluated in terms of relevance to the study.

Please respond to the questionnaire selecting the number next to the following questions that best corresponds to your evaluation: $1=$ very insufficient; $2=$ insufficient; $3=$ fair $/$ moderate; 4 = good; and 5 = excellent.

1 How would you evaluate the following leadership competencies in yourself?

Compassion

Advocacy skills

Consulting skills

Empathy

Ability to influence

Self-management

Relationship management

Authenticity (transparency)

Integrity

Ability to gain the trust of others

Personal responsibility

Conflict management

Group/team leadership

Dealing with difficult people

Probability of exercising leadership during a crisis $\begin{array}{lllll}1 & 2 & 3 & 4 & 5\end{array}$

$\begin{array}{lllll}1 & 2 & 3 & 4 & 5\end{array}$

$\begin{array}{lllll}1 & 2 & 3 & 4 & 5\end{array}$

$\begin{array}{lllll}1 & 2 & 3 & 4 & 5\end{array}$

$\begin{array}{lllll}1 & 2 & 3 & 4 & 5\end{array}$

$\begin{array}{lllll}1 & 2 & 3 & 4 & 5\end{array}$

$\begin{array}{lllll}1 & 2 & 3 & 4 & 5\end{array}$

$\begin{array}{lllll}1 & 2 & 3 & 4 & 5\end{array}$

$\begin{array}{lllll}1 & 2 & 3 & 4 & 5\end{array}$

$\begin{array}{lllll}1 & 2 & 3 & 4 & 5\end{array}$

$\begin{array}{lllll}1 & 2 & 3 & 4 & 5\end{array}$

$\begin{array}{lllll}1 & 2 & 3 & 4 & 5\end{array}$

$\begin{array}{lllll}1 & 2 & 3 & 4 & 5\end{array}$

$\begin{array}{lllll}1 & 2 & 3 & 4 & 5\end{array}$

$\begin{array}{lllll}1 & 2 & 3 & 4 & 5\end{array}$

2 Of the skills listed above, which do you think will be most beneficial to you as a dentist?

3 Of the skills listed above, which do you think will be least beneficial to you as a dentist?

4 How likely do you think you will be to continue to practice developing your leadership skills? ( ) Very likely ( ) Likely ( ) Unlikely

Please answer 5-8, with a few words or short phrases.

5 If you are able to develop your leadership skills which of the skills listed are you most likely to focus on developing?

6 Do you think the creation of an activity on leadership and management in UFPB is important?

7 Would you participate in a course on leadership and management?

8 What would you like to learn in a course on leadership and management?

Figure 1. Personalized questionnaire for students developed for this study. 
This research was submitted to the Research Ethics Committee of the Center for Health Sciences, UFPB (Comitê de Ética e Pesquisa do Centro de Ciências da Saúde - CEP / CCS) and received approval $n^{\circ} .0338 / 14$.

\section{RESULTS}

Twenty-eight students were enrolled in the first semester of the fifth year of dentistry at UFPB, and 26 of these students responded to the questionnaire.

It was observed that these students evaluated their current general leadership skills at 3.42 on a scale from one (very poor) to five (excellent). On average, they rated themselves best on "Integrity" (4.42 points) and worst on "Advocacy Skills" (2.38 points) (Table 1$)$.

Table 1. First semester fifth-year students' responses to evaluation of current leadership skills

\begin{tabular}{lclc}
\hline \multicolumn{1}{c}{ Leadership skill } & Score & \multicolumn{1}{c}{ Leadership skill } & Score \\
\hline Compassion & 4.07 & Integrity & 4.42 \\
Advocacy skills & 2.38 & $\begin{array}{l}\text { Ability to build the trust with } \\
\text { others }\end{array}$ & 4.19 \\
Inquiry skills & 3.88 & Personal responsibility & 4.19 \\
Empathy & 3.73 & Managing conflict & 3.38 \\
Ability to influence & 3.53 & Leadership group/team & 3.65 \\
Self-management & 3.61 & Dealing with difficult personalities & 3.23 \\
Relationship management & 3.46 & Likelihood to exercise leadership & 3.23 \\
& & during a crisis & \\
Authenticity (transparency) & 4.23 & General evaluation & 3.42 \\
\hline Note: Scale of 1 (very poor) to 5(excellent) & & &
\end{tabular}

Of the 15 skills discussed, the "capacity to build the trust of others" was most frequently identified by the first semester fifth-year students as the aspect most beneficial for a dentist, representing $23.08 \%$ of responses, while "compassion" was the skill most widely considered least beneficial, with $34.62 \%$ of responses (Table 2).

Twelve (46.15\%) of the 26 students who responded to the questionnaire indicated that it was "very likely" that they would practice developing their leadership skills. None of them thought this possibility was not very likely, as observed in Table 3.

When asked what skill they would most likely focus on developing, students reported that it would be the skill of "Dealing with difficult personalities", with $15.37 \%$ of responses (Table 4).

Table 5 shows that all students questioned felt it to be important to create a leadership and management activity within the UFPB dentistry course.

Only one student $(3.85 \%)$ reported that they would not participate in a leadership and management course (Table 6). 
Table 2. First semester fifth-year students' evaluation of the fifteen questionnaire leadership abilities.

\begin{tabular}{|c|c|c|c|c|}
\hline \multirow{2}{*}{ Leadership skills } & \multicolumn{2}{|c|}{ Most beneficial skill } & \multicolumn{2}{|c|}{ Least beneficial skill } \\
\hline & Points & $\%$ & Points & $\%$ \\
\hline Compassion & 0 & $0 \%$ & 9 & $34.62 \%$ \\
\hline Advocacy skills & 0 & $0 \%$ & 3 & $11.53 \%$ \\
\hline Inquiry skills & 3 & $11.53 \%$ & 0 & $0 \%$ \\
\hline Empathy & 1 & $3.85 \%$ & 1 & $3.85 \%$ \\
\hline Ability to influence & 0 & $0 \%$ & 5 & $19.23 \%$ \\
\hline Self-management & 4 & $15.38 \%$ & 0 & $0 \%$ \\
\hline Relationship management & 0 & $0 \%$ & 0 & $0 \%$ \\
\hline Authenticity (transparency) & 1 & $3.85 \%$ & 0 & $0 \%$ \\
\hline Integrity & 5 & $19.23 \%$ & 0 & $0 \%$ \\
\hline $\begin{array}{l}\text { Ability to build the trust with } \\
\text { others }\end{array}$ & 6 & $23.08 \%$ & 0 & $0 \%$ \\
\hline Personal responsibility & 5 & $19.23 \%$ & 1 & $3.85 \%$ \\
\hline Managing conflict & 0 & $0 \%$ & 3 & $11.53 \%$ \\
\hline Leadership group/team & 0 & $0 \%$ & 1 & $3.85 \%$ \\
\hline $\begin{array}{l}\text { Dealing with difficult } \\
\text { personalities }\end{array}$ & 1 & $3.85 \%$ & 1 & $3.58 \%$ \\
\hline $\begin{array}{l}\text { Likelihood to exercise } \\
\text { leadership during a crisis }\end{array}$ & 0 & $0 \%$ & 2 & $7.69 \%$ \\
\hline Total & 26 & $100 \%$ & 26 & $100 \%$ \\
\hline
\end{tabular}

Table 3. Students' responses regarding the probability of practicing the development of leadership skills. (Probability of practicing the development of leadership skills)

\begin{tabular}{lcc}
\hline Probability & $\mathrm{N}$ & $\%$ \\
\hline Very likely & 12 & $46.15 \%$ \\
Somewhat likely & 14 & $53.85 \%$ \\
Not very likely & 0 & $0 \%$ \\
\hline Total & 26 & $100 \%$ \\
\hline
\end{tabular}


Table 4. Skills that first semester fifth-year students are most likely to focus on developing.

\begin{tabular}{lcc}
\hline Skills most likely to focus on developing & N & $\%$ \\
Skills & 1 & $3.85 \%$ \\
\hline Compassion & 1 & $3.85 \%$ \\
Advocacy skills & 1 & $3.85 \%$ \\
Inquiry skills & 0 & $0 \%$ \\
Empathy & 2 & $7.69 \%$ \\
Ability to influence & 2 & $7.69 \%$ \\
Self-management & 2 & $7.69 \%$ \\
Relationship management & 0 & $0 \%$ \\
Authenticity (Transparency) & 1 & $3.85 \%$ \\
Integrity & 1 & $3.85 \%$ \\
Ability to build the trust with others & 1 & $3.85 \%$ \\
Personal responsibility & 1 & $3.85 \%$ \\
Managing conflict & 2 & $7.69 \%$ \\
Leadership group/team & 4 & $15.37 \%$ \\
Dealing with difficult personalities & & \\
Likelihood to exercise leadership during a & 2 & $7.69 \%$ \\
crisis & 5 & $19.23 \%$ \\
Not reported & 26 & $100 \%$ \\
\hline Total & &
\end{tabular}

Table 5. First semester fifth-year students' rating of the importance of creating a leadership and management activity. (Is it important to create a leadership and management activity in the UFPB dentistry course?)

\begin{tabular}{lcc}
\hline & $\mathrm{N}$ & $\%$ \\
\hline Yes & 26 & $100 \%$ \\
No & 0 & $0 \%$ \\
\hline Total & 26 & $100 \%$ \\
\hline
\end{tabular}

\section{DISCUSSION}

The data obtained in this study reinforce the need for the creation of a leadership activity in the UFPB dental course. The need for cultural competence, the demand for patient safety, and the
Table 6. Participation of first semester fifth-year students in a leadership and management course. (Would you participate in a leadership and management course?)

\begin{tabular}{lcc}
\hline & $\mathrm{N}$ & $\%$ \\
\hline Yes & 25 & $96.15 \%$ \\
No & 1 & $3.85 \%$ \\
\hline Total & 26 & $100 \%$ \\
\hline
\end{tabular}


present study lies in the fact that the HSDM data was collected at the end of the Leadership course, meaning that it was possible for the student to know in depth the leadership and management skills that were being evaluated. In the UFPB study, the data obtained concern each student's individual knowledge of the topics covered, so it is difficult to compare data.

In fact, no one can compare the results of similar surveys in different schools because each school has developed a unique evaluation tailored to its own goals ${ }^{7}$.

In UFPB, the general average score for current leadership skills reported by students was 3.42. Students rated themselves best on "Integrity" (4.42 points) and worst in "Advocacy skills" (2.38). There was unanimity among respondents regarding the necessity to create a leadership course at UFPB. They also found it important to focus on developing the ability to "Dealing with difficult personalities". In this regard, Morita et al. ${ }^{8}$ emphasize that human relationships, from the first moments of the dentistry course, improve the understanding of managing staff.

A major limitation of this type of evaluation is that most of the data on students in relation to changes in skills development are self-reported: the students reflect upon and report their own perceived progress in the development of competencies. Although students may overestimate their skills development, the fact that levels of perceived expertise increase, rather than changes in the perceived importance of certain subjects, lends credence to the idea that skill levels actually increase. To measure actual levels of student ability, particularly over time, future studies are needed and will require more resources than were used by the authors of this study ${ }^{7}$.

There is currently no course in leadership and management in dentistry at UFPB. However, certain topics covered at HSDM are dealt with during the dentistry course. Over a two-year period, students take classes in basic health care and acquire concepts about public health, always with regard to the Unified Health System (Sistema Único de Saúde - SUS), which is the public health system of Brazil. However, at no time are leadership topics discussed, nor topics pertaining to the management of consulting rooms, whether public or private, or research laboratories. Situations such as team building, conflict management, disparities in oral health, negotiation, and communication are not addressed during the course. On this subject, Morita et al. ${ }^{8}$ conclude that the skills of leadership, administration, and management merit greater improvement in their implementation in the curriculum of dentistry courses in Brazil.

While the health care system of the United States has a high level of medical experience and advanced technology, it is not robust enough to apply this knowledge in a conscious, safe, timely, patientcentered, and equitable manner. Health professionals should seek patient-centered solutions, i.e., solutions of a humane and respectful nature, according to individuals' needs and preferences. The system should be fairer and should meet the needs of all Americans, regardless of race, ethnicity, place of residence, or socioeconomic status ${ }^{9}$.

The SUS has the principles of 
universality, comprehensiveness, equity, decentralization, and social participation. Statistics show a declining trend in oral health problems such as tooth decay and tooth loss; however, problems still occur regarding inadequate access to care. Reduction in socioeconomic disparities and public health measures for the most vulnerable groups remain a challenge for the establishment and implementation of public policies in Brazil ${ }^{5,6}$.

Technician training is present in most educational institutions in Brazilian dentistry, where there is also a valuing of the basic sciences that tends to overlook aspects of health promotion and prevention. However, the current PPPCOs are trying to adapt to the reality proposed by SUS, which aims to introduce professional training more appropriate to individual primary and general care perspectives ${ }^{10}$. However, concepts regarding the inclusion of leadership and management, whether in public or private service, have not been observed in the PPPCOs.

Drawing a parallel between the two courses, UFPB and HSDM, reveals that in the HSDM course, ethics is approached through case studies that include functional systems and group dynamics. This approach aims to increase the security of the professional and patient and to avoid mistakes. To that end, skills that are rarely taught in dental schools are required ${ }^{3}$.

UFPB already has the Ethics and Law in Dentistry discipline, which examines knowledge of the law and the duties of the dentist, patient, and society, focusing on legislation regulating profession and professional responsibility. However, this topic is taught in the fourth year, after students have already taken most clinics without this specific knowledge. The justification for this sequence is that at the beginning of the course, the students do not have the clinical experience to judge and understand what is discussed in the ethics discipline.

Education in truly understanding cultural differences and providing students with tools to be able to interact with all patients and staff in an effective and respectful manner was not performed until the Leadership and Management course at $\mathrm{HSDM}^{3}$. This questionnaire is the first step towards the creation of a leadership in dentistry course at UFPB, aiming to broaden students' horizons regarding the skills developed at HSDM.

In Brazil, more specifically in UFPB, there are large social and cultural differences among patients, teachers, and students themselves. For example, although the university is public, the law of quotas allocates vacancies to students who attended public schools, students with low family income, blacks, colored, and Indians ${ }^{11}$. These students often do not receive financial incentives to acquire the instruments required by the course to participate in the clinics. Dealing with such situations is part of the reason that leadership concepts need to be acquired.

The UFPB is also partnered with the SUS, and patients in various cities in the state of Paraíba, Brazil, are treated in the clinical schools of the institution. There are also exchange programs with other countries. In the UFPB dentistry course, the main partnership is with students from Africa. It is thus possible to observe a large mix of races and cultures with which students interact in their daily lives. 
However, despite the need to provide patient care with ethics, compassion, and respect for differences, more than a third of the UFPB students cited compassion as the least beneficial skill for the dentist. This idea is in conflict with the statement by Goleman ${ }^{4}$, who emphasizing the importance of compassion cites a patient's open letter to his surgeon, stating, "having compassion is more than holding a hand. It is the equivalent of a good remedy."

It is essential that after the creation of the new UFPB course, an evaluation and comparison are performed of the students' actual perception of the importance of leadership skills, grounded in scientific concepts and evidence.

\section{CONCLUSIONS}

This study evaluated UFPB dental students' perceptions regarding leadership and management and the need to instruct students on the subject. It was proven that there was little knowledge about leadership and that there is a great need to create a course. There was great acceptance on the part of students regarding the creation of a leadership and management activity at UFPB.

\section{REFERENCES}

1. de Albuquerque E L. José Américo de Almeida e as raízes do ensino superior na Paraíba. Inform. CRO-PB. 2010; 32(1): 1 .

2. Morita MC, Kriger L. Mudanças nos cursos de Odontologia e a interação com o SUS. Rev ABENO. 2004;4(1):17-21.
3. Kalenderian E, Skoulas A, Timothé P, Friedland B. Integrating Leadership into a Practice Management Curriculum for Dental Students; J Dent Educ. 2010;74(5):464-71.

4. Goleman D. Emotional intelligence: why it can matter more than IQ. New York: Bantam Books, 1995.

5. Narvai PC, Frazão P, Roncalli AG, Antunes AG, Leopoldo J. Cárie dentária no Brasil: declínio, iniquidade e exclusão social. Rev Panam Salud Publica. 2006;19(6):385-93.

6. Roncalli AG, Côrtes MI de S, Peres, KG. Oral health epidemiology and surveillance models in Brazil; Cad Saúde Públ. 2012; 28 Suppl:s58-68.

7. Goldstein AO, Calleson D, Bearman R, Steiner BD, Frasier PY, Slatt L. Teaching advanced leadership skills in community service (ALSCS) to medical students. Acad Med. 2009;84(6):754-64.

8. Morita MC, Kriger L, de Carvalho ACP, Haddad AE. Implantação das Diretrizes Curriculares Nacionais em Odontologia. 2ed. Maringá: Dental Press, 2013.

9. Institute of Medicine, Committee on Quality of Health Care in America. Crossing the Quality Chasm: A New Health System for the 21st Century. Washington, DC: National Academy Press; 2001.

10. Freixinho ABS, Chevitarese L. Abordagem na formação do cirurgiãodentista clínico geral para atuar no serviço público e privado. Revolução na prática de ensino [Approach to general practitioner dentist training for work in public and private service. A 
revolution in teaching practice]; Rev ABENO. 2010;10(1):14-8.

11. Brasil. Lei $n^{\circ} 12.711$, de 29 de agosto de 2012. Dispõe sobre o ingresso nas universidades federais e nas instituições federais de ensino técnico de nível médio e dá outras providências [On admission to federal universities and federal institutions of middle level technical education and other measures]. Diário Oficial da União. 15 Aug 2012. Available at: http://legislacao.planalto.gov.br/legisl a/legislacao.nsf/Viw_Identificacao/lei \%2012.711-2012?OpenDocument

\section{RESUMO}

Conhecimento de liderança e de gestão: Estudo piloto das percepções dos estudantes de um curso de odontologia em uma universidade no Brasil

O Curso de Odontologia na Universidade Federal da Paraíba (UFPB), Brasil, foi criado em 1955. Embora seja um curso reconhecido pela sua alta qualidade no ensino técnico da odontologia, até 2014 não possuía nenhuma disciplina de liderança e gestão mesmo entendendo-se que essas habilidades precisam ser alimentadas e desenvolvidas ao longo da vida. O objetivo do presente trabalho foi avaliar a percepção do conhecimento sobre liderança e gestão dos estudantes do quinto ano do curso de odontologia da UFPB. Os alunos responderam a um questionário e avaliaram suas habilidades de liderança atuais em uma escala de um (muito insuficiente) a cinco (excelente), em média, eles avaliaram a si mesmos melhores em "Integridade" (4,42 pontos) e o pior em "Habilidades em advocacia" (2,38 pontos). A "Capacidade de construir a confiança dos outros" foi o aspecto considerado mais benéfico para um cirurgião-dentista, representando 23,08\% das respostas, enquanto "compaixão" foi a habilidade considerada menos benéfica, com $34,62 \%$ das respostas. Todos os alunos questionados acharam que é importante criar uma disciplina de liderança e gestão no curso de odontologia da UFPB. Esse artigo avaliou a percepção de liderança e gestão dos alunos de odontologia da UFPB e a necessidade de instruir aos alunos sobre $\mathrm{o}$ assunto. Comprovou-se que houve pouco conhecimento sobre liderança e há uma grande necessidade de criação do curso de liderança na UFPB.

Descritores: Liderança. Educação em Odontologia. Estudantes de Odontologia. Gestão de Pessoas.

Correspondência para:

Fábio Luiz Cunha D'Assunção

e-mail: fabioendodontia@gmail.com

Centro de Ciências da Saúde, Departamento de Odontologia Restauradora

58051-900 Cidade Universitária - João Pessoa/PB 